\title{
A rarely seen congenital malformation in an elderly patient: Uhl's anomaly
}

\section{Yaşlı bir hastada nadir bir konjenital malformasyon: Uhl's anomalisi}

\author{
Nurşen KELEŞ ${ }^{1}$, Serçin ÖZKÖK ${ }^{2}$, Şeref KUL ${ }^{1}$, Kenan DEMIRCiOĞLU ${ }^{1}$, Mustafa ÇALIŞKAN ${ }^{1}$
}

\section{ABSTRACT}

Uhl's anomaly (UA) is a rare congenital malformation described as the partial or complete absence of the myocardium of the right ventricle. UA is commonly confused with arrhythmogenic right ventricular dysplasia or Ebstein's anomaly. Cardiac magnetic resonance imaging (MRI) is the gold standard diagnostic technique for the differential diagnosis of UA. Here, we report a rare case of UA which had been misdiagnosed as Ebstein's anomaly in a 62-year-old female.

Keywords: Uhl's anomaly, cardiac magnetic resonance, right ventricle
Öz

Uhl's Anomalisi (UA) sağ ventrikülde parsiyel ya da total miyokard yokluğu ile tanımlanan nadir bir konjenital malformasyondur. UA sıklıkla aritmojenik sağ ventrikül displazisi veya Ebstein's anomalisi ile karıştırılır. UA'nın ayırıcı tanısında kardiyak magnetik rezonans görüntüleme, altın standart tanı tekniğidir. Burada nadir olarak 62 yaşında Ebstein's anomalisi yanlış tanısı almış bir UA olgusunu sunacağız.

Anahtar kelimeler: Uhl's anomalisi, kardiyak magnetik rezonans görüntüleme, sağ ventrikül

\section{INTRODUCTION}

The partial or complete absence of the myocardium of the right ventricle is defined as Uhl's anomaly (UA). It was reported as a very rare congenital malformation in a review which included 84 reported cases in the literature from the beginning of $20^{\text {th }}$ century to 1993. It may be isolated or related with other congenital cardiac malformations ${ }^{1,2}$. Although the exact pathophysiology is not obvious, primary nondevelopment of the myocytes and the apoptosis of the myocytes are the two different theories for the explanation of the etiology ${ }^{2}$. Cardiac magnetic resonance imaging (MRI) findings in UA are right ventricular dilatation with the absence of the right ventricular myocardium, hypokinetic wall movements and related tricuspid valve regurgitation. Here, we report a rare case of UA, which had been misdiagnosed as Ebstein's anomaly in a 62-year-old female.

\section{CASE REPORT}

A 62-year-old female was admitted to our outpatient clinic with exertional dyspnea. On physical examination there was mild pretibial edema and jugular vein distention with no cyanosis. Pansystolic murmur was present at the apex. She had been diagnosed as Ebstein's anomaly during childhood. Transthorasic echocardiography (TTE) which was performed on admission revealed distinct dilatation of right atrium and right ventricle with right ventricular systolic dysfunction and severe tricuspid valve regurgitation. The systolic function and the diameters of the left ventricle were normal. We also observed a thin endocardial and epicardial layer of right ventricle parallel to each other which was consistent with the absence of myocardium of the right ventricle (Figure $1 a, b)$. Therefore cardiac MRI was planned in order to diagnose the absence of the right ventricular myo-

Received: 28.12 .2016

Accepted: 19.01.2017

${ }^{1}$ Istanbul Medeniyet University, Göztepe Training and Research Hospital, Department of Cardiology, Istanbul, Turkey

${ }^{2}$ Istanbul Medeniyet University, Göztepe Training and Research Hospital, Department of Radyology, Istanbul, Turkey

Yazışma adresi: Nurşen Keleş, Istanbul Medeniyet University, Göztepe Training and Research Hospital, Department of Cardiology, Istanbul, Turkey

e-mail: drnursenkeles@yahoo.com.tr 
cardium. Steady-state free-precession (SSFP) cardiac MRI images demonstrated a marked dilatation of the right atrium and the right ventricle with the complete absence of the right ventricular myocardial layer (white arrows) (Figure 2a,b) The left ventricle was constricted and displaced laterally on long-axis fourchamber views. The ejection fraction of the right ventricle was calculated as $25 \%$. The end-diastolic, and the end-systolic volume indices of right ventricle were 147.1 and $109.6 \mathrm{ml} / \mathrm{m} 2$ respectively. Tricuspid valve hinged normally and was not dysplastic. The severe tricuspid valve regurgitation was considered to be due to annular dilatation.

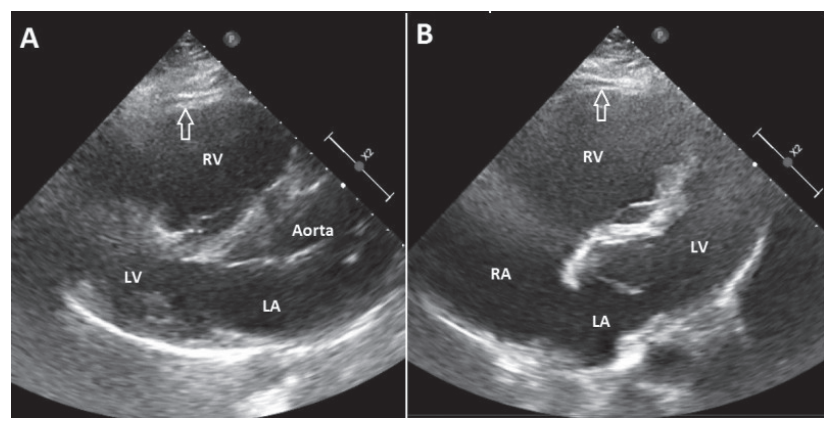

Figure 1. Transthorasic echocardiography parasternal long axis (A) and apical four chamber (B) views demonstrated dilatation of right chambers and a thin endocardial and epicardial layer of right vetricle parallel to each other (arrows) which was consistent with the absence of myocardium of right ventricle.

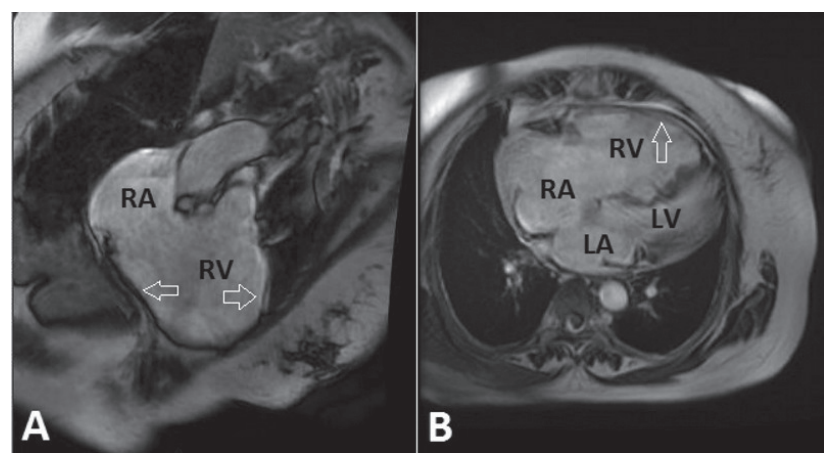

Figure 2. Cardiac magnetic resonance imaging steady-state free-precession (SSFP) images showed marked dilatation of the right atrium and the right ventricle with the complete absence of the right ventricular myocardial layer (white arrows).

She had been diagnosed as Ebstein's anomaly during childhood and had been followed as Ebstein's anomaly till date. However, we showed that she did not have Ebstein's anomaly, actually she had UA which was demonstrated with cardiac MRI.

\section{DISCUSSION}

UA is described as a rare cardiomyopathy with a thin walled dilated right ventricle because of the absence of myocardium. Firstly, Osler demonstrated a heart with a very thin wall like a parchment. Afterwards, Uhl reported a similar case after an autopsy of an old infant and thereafter, Fontaine et al. defined a condition named as "arrhythmogenic right ventricular dysplasia" (ARVD) featured by local deficiency or fibro-fatty replacement of the right ventricular myocardium. UA and ARVD has distinct and different morphological properties. In UA, the affected wall is not replaced by a fat tissue, and endocardial and epicardial layer are parallel to each other, while in ARVD, myocardial tissue is replaced by fibrous fatty tissue ${ }^{1,2}$. One of the possible causes of UA is the failure of the development of the right ventricular myocardium during embryonic period. Recently a hypothesis that the right ventricular myocardium may be destroyed because of a cascade of apoptosis of the myocardiocytes has been introduced based on trials in molecular biology ${ }^{2}$.

Ebstein's disease or Ebstein's anomaly is defined as a rare and interesting congenital malformation of the tricuspid valve. The malformed tricuspid valve may be stenotic, incompetent, or rarely, imperforate $^{3}$. Uhl's anomaly is often misdiagnosed as ARVD or Ebstein's anomaly like in the present case and cardiac MRI complementary to TTE may be a useful diagnostic tool for differential diagnosis of UA.

Most of the patients with Uhl's anomaly require surgical treatment during childhood to lead a normal life. The surgical approaches for the treatment of Uhl's anomaly involve one and a half ventricle repair with partial right ventriculectomy, a bidirectional Glenn procedure with atrial septectomy and separation of the main pulmonary artery followed by plicating of the RV cavity and cardiac transplantation ${ }^{4}$.

Many of the patients with Uhl's anomaly die in infancy or childhood without surgical treatment. In the present case the patient with Uhl's anomaly had 
nearly normal life span without surgical treatment. In the literature only a few cases with UA were reportedly survived till advanced ages without surgical treatment $^{5,6}$.

\section{Conflicting interest}

One of the authors of this work was excluded from the evaluation process because he is a member of the journal's editorial board.

\section{Funding}

The authors received no financial support for the research and/or authorship of this case report.

\section{REFERENCES}

1. Epstein ML. Congenital stenosis and insufficiency of tricuspid valve. Uhl's anomaly. Moss and Adams Hearts Disease of Infant, Children and Adolescents. $6^{\text {th }}$ ed. Lippincott Willams and Wilkins, Phildelphia; 2000. p. 816-8.

2. Perloff JK, editor. Uhl's anomaly. In: The Clinical Recognition of Congenital Heart Disease. $5^{\text {th }}$ ed. Philadelphia: Saunders; 2003. p. 209-15.

3. Goksin I, Baltalarlı A, Evrengul M, et al. Ebstein's anomaly in a 16-year-old child presenting with cyanosis and syncope. Turk Gogus Kalp Dama 2008;16:183-5.

4. Ganczar J, English R. Uhl's anomaly: Absence of the right ventricular myocardium. Ann Pediatr Cardiol 2015;8:71-3. https://doi.org/10.4103/0974-2069.149529

5. Song BG. A rare case of partial absence of the right ventricular musculature in asymptomatic adult man: partial Uhl's anomaly. Heart Lung 2013;42:215-7. https://doi.org/10.1016/j.hrtlng.2013.02.001

6. Güler N, Demirbag R, Eryonucu B, Gül A. A case of successful six consecutive deliveries in a 41-year-old woman with Uhl's anomaly. Int J Cardiol 2003;87:283-5. https://doi.org/10.1016/S0167-5273(02)00306-6 